\title{
Investigation on Diet of Long-Eared Owl (Asio Otus) Inhabiting Fatih Natural Park (Turkey)
}

\author{
Tarkan YORULMAZ $^{1 *}$ Nurhan ARSLAN ${ }^{2}$ \\ ${ }^{1}$ Çankırı Karatekin Üniversitesi, Yapraklı Meslek Yüksek Okulu, Ormancılık Bölümü, Avcılık ve Yaban Hayatı \\ Programi, Ballıca Yerleşkesi, Çankırı \\ ${ }^{2}$ Çankırı Karatekin Üniversitesi, Fen Bilimleri Enstitüsü, Rektörlük Ek Hizmet Binası, Yeni Mahalle, Çankırı \\ (ORCID:0000-0002-9033-7162) (ORCID: 0000-0002-4928-4767)
}

\begin{abstract}
Pellet analyses were used to identify small mammal species in the diet of this owl species in order to reveal its ecological role. In this study, 706 pellets of Asio otus were collected from 3 different localities in Fatih Natural Park between February and March 2014. Pellets were dissolved by using 3\% $\mathrm{NaOH}$ solution and then bones were dehydrated and identified. The aim of this study was to determine mammal composition in the diet of Asio otus inhabiting Fatih Natural Park of Yozgat Province, Turkey. Residues of bone from 1293 individuals/preys corresponding to $42377.41 \mathrm{~g}$ biomass in total were detected as the result of analysis. These individuals were identified to belonging to 12 mammal species (Crocidura suaveolens, Suncus etruscus, Microtus hartingi/lydius, Microtus levis, Microtus sp., Cricetulus migratorius, Mesocricetus brandti, Apodemus sp., Apodemus sylvaticus, Apodemus witherbyi, Mus macedonicus, and Meriones tristrami) from 3 families and 8 genera. Microtus hartingi/lydius, which is known as agricultural pest, was dominant in the diet of Asio otus. When diversity of mammal species within the food composition was examined, Asio otus nesting in forest was found to primarily prefer agricultural and steppe areas, and was also found in woody and bushy areas. The use of Asio otus can be taken into consideration when dealing with rodent species known as agricultural pests.
\end{abstract}

Keywords: Asio otus, Diet, pellets, small mammals, Yozgat, Turkey.

\section{Fatih Tabiat Parkı'ndaki Uzun Kulaklı Orman Baykuşu (Asio otus)'nun Diyetinin İncelenmesi}

\begin{abstract}
$\ddot{O} \mathbf{z}$
Pellet analizleri belli bir alanda yaşayan küçük memeli türlerinin tespitinde ve baykuşun o alandaki ekolojik rolünün ortaya konmasında kullanılmaktadır. Bu çalışma Yozgat Fatih Tabiat Parkından Şubat ve Mart 2014 tarihlerinde Asio otus bireyine ait 3 farklı lokaliteden toplanan 706 pellet üzerinde yapılmışıı. Pelletler \%3'lük $\mathrm{NaOH}$ solüsyonu kullanılarak çözülmüş ve daha sonra kemikler kurutulup teşhis edilmiştir. Bu çalışma ile Yozgat Fatih Tabiat Parkında yaşadığı tespit edilen Asio otus bireylerinin diyetindeki memeli kompozisyonunu belirlemek amaçlanmıştır. Yapılan analizler sonucunda toplam 42377,41 gr biomasa karşılık gelen 1293 bireye/ava ait kemik kalıntısı tespit edilmiştir. Bu bireylerin 3 familya ve 8 cins ait toplam 12 memeli türüne (Crocidura suaveolens, Suncus etruscus, Microtus hartingi/lydius, Microtus levis, Microtus sp., Cricetulus migratorius, Mesocricetus brandti, Apodemus sp., Apodemus sylvaticus, Apodemus witherbyi, Mus macedonicus ve Meriones tristrami) ait olduğu saptanmıștır. Tarım zararlısı olarak bilinen Microtus hartingi/lydius türünün Asio otus' un diyetinde ilk sırayı aldığı tespit edilmiştir. Besin kompozisyonundaki memeli türlerinin çeşitliliğine bakıldığında orman içinde yuvalanan Asio otus' un beslenme amacı ile öncelikli olarak tarım ve step alanları tercih ettiği, bununla birlikte ormanlık ve çalılık alanlarda da beslendiği saptanmıştır.
\end{abstract}

Anahtar kelimeler: Asio otus, diet, pellet, Küçük memeliler, Yozgat, Turkey.

"Sorumlu yazar: tarkan.yorulmaz@gmail.com

Geliş Tarihi: 30.03.2019, Kabul Tarihi: 21.04.2019 


\section{Introduction}

Owls, a member of order strigiformes, are known as myofagus bird species. Pellet structures formed by owls are used to identify mammal species in a certain area and the habitats where they are active [1-3]. Obuch [4] gave new records of several bat species for bat fauna in Turkey depending on pellets collected from in front of a cave in Kahta district of Adiyaman Province. In the same study, the researcher also determined existence of bird and rodent species in the pellets. Studies on food composition through analysis of pellets of owls from various locations in Anatolia have been conducted [2, 5-16].

The aim of this study was to determine species' food preference by analyzing 706 pellets of Asio otus which were detected to live in Fatih Natural Park of Yozgat Province. Information regarding the mammal habitats where Asio otus is active was also tried to obtain.

\section{Material and Method}

\subsection{Study Area}

Field studies were conducted in three different localities that were close to each other (UTM-36S 655788 E 4407843 N; 655917 E 4407905 N; 656066 E 4407900 N) in Fatih Natural Park of Yozgat Province between 14 February 2014 and 14 March 2014. The study area is a woody zone consisting of dense pine trees and there are sporadic glades and seasonal streams in some places. The city center of Yozgat is located at approximately $1 \mathrm{~km}$ north of the study field, agricultural lands and steppe areas are at about $1.2 \mathrm{~km}$ east (Figure 1).

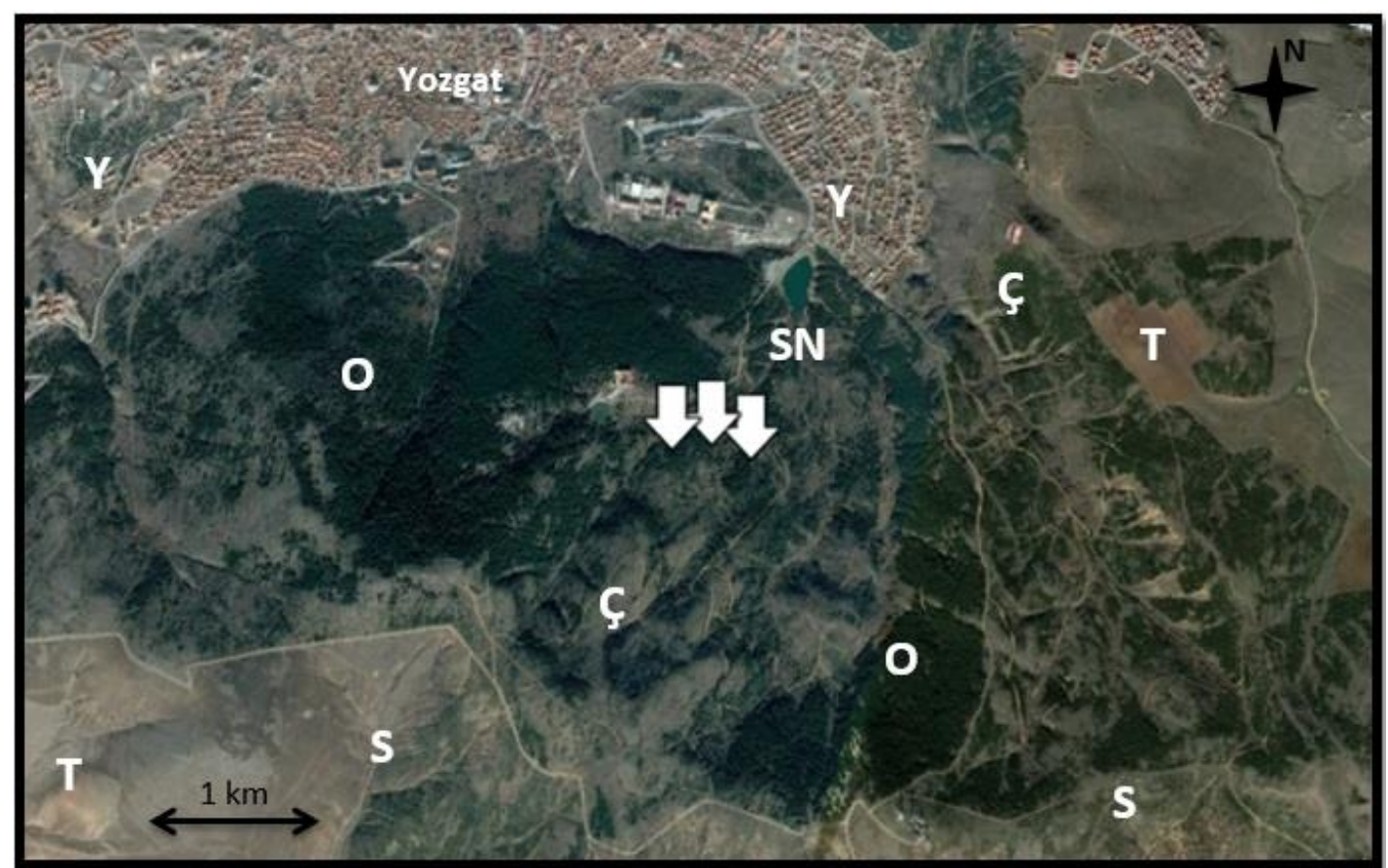

Figure 1. Localities where the pellets were collected (white arrows) and diverse habitats found around (Habitat Types: T-Agricultural, O-Forest, SN- Marshy and Damp, S-Steppe, Y-Settlements)

\subsection{Pellet Analysis}

In total, 706 pellets were collected from the study area. Analyses were carried out according to Schueler [17] and Yalden [18]. Hairs included in pellets were ensured to lyse by dissolving pellets in $3 \% \mathrm{NaOH}$ solution. Pellets were kept in hot water bath at $65^{\circ} \mathrm{C}$ for 45 minutes. Pellets, then, were dehydrated in petri dishes. Weight of each pellet, number of bone pieces, number of individuals, number of species, 
and biomass were identified. Biomass values were determined considering average of weights in studies conducted about species around close areas [19-23].

\subsection{Prey Identification}

Internal character measurements of skulls from mammal species identified were recorded by measuring via caliper with $10 \mathrm{~mm}$ precision. Pieces of skull and teeth belonging to each species were photographed by usingLeica M125 stereo-microscope. Pamukoğlu and Albayrak [24], Osborn [25], Tez [26], Kefelioğlu and Krystufek [27], Yiğit and Çolak [19], Krystufek and Vohlarik [20], Demirbaş and Pamukoğlu [21], Gözütok and Albayrak [22], Yorulmaz and Albayrak [23], Coşkun [28] and Yiğit [29] were followed for identification of species. Materials were conserved in Zoology Laboratory of Biology Department, Faculty of Science, Çankırı Karatekin University.

\section{Results}

As a result of examining 706 collected pellets, a total of 12 species were identified including Crocidura suaveolens, Suncus etruscus, Microtus hartingi/lydius, Microtus levis, Microtus sp., Cricetulus migratorius, Mesocricetus brandti, Apodemus sylvaticus, Apodemus witherbyi, Apodemus sp., Mus macedonicus and Meriones tristrami from Crocidura, Suncus, Microtus, Cricetulus, Mesocricetus, Apodemus, Meriones, and Mus species from Soricidae, Cricetidae, and Muridae families in Eulipotyphla and Rodentia orders (Table 1).

Mean pellet weight was $2.69 \mathrm{~g}$, mean bone weight in each pellet was $1.32 \mathrm{~g}$, average number of bones was 94.4 in each pellet, and mean number of individuals per pellet was 1.8. 801 individuals (61.95\%) from 5 species of Cricetidae family and 686 individuals (53\%) from 3 species of genus Microtus were were identified in diet of long-eared owl. The species Microtus hartingi/lydius among them was placed at the top with $490(37.90 \%)$ individuals. Long-eared owl was determined to consume $42377.41 \mathrm{~g}$ biomass in 706 pellets. Among the consumed mass, the species Microtus hartingi/lydius with $22589 \mathrm{~g}(53.3 \%)$ was detected to take the first place again.

Among the identified species, Microtus hartingi/lydius,Meriones tristrami, Cricetulus migratorius, Mesocricetus brandti Mus macedonicuswere mainly found in steppes, agricultural areas, and glades; Crocidura suaveolens, Suncus etruscus, Microtus levis, Mus macedonicus, Apodemus witherbyi were in areas close to human settlements, riparian areas, and shrubbery zones; Apodemus witherbyi, Apodemus sylvaticus in underbrush under trees within woodlands.

When diet of long-eared owl was considered in terms of habitat distributions, it was determined as follows; agricultural areas ( 7 species), shrubbery zones (6 species), steppes (6 species), marshy and damp areas ( 5 species), forests ( 3 species) and settlements (1 species) (Table 1$)$.

Table 1. Overall frequency and proportions of various prey items in the diet of Long eared owl

\begin{tabular}{|l|c|c|c|c|c|c|}
\hline Species & $\begin{array}{c}\text { Number of } \\
\text { Individuals }\end{array}$ & $\begin{array}{c}\text { Percent } \\
(\boldsymbol{\%})\end{array}$ & $\begin{array}{c}\text { Body } \\
\text { Weight }(\mathbf{g r})\end{array}$ & $\begin{array}{c}\text { Total Biomass } \\
(\mathbf{g r})\end{array}$ & $\begin{array}{c}\text { Percent } \\
(\boldsymbol{\%})\end{array}$ & $\begin{array}{c}\text { Habitat } \\
\text { Type }\end{array}$ \\
\hline Microtus hartingi/lydius & 490 & 37.9 & 46.1 & 22589 & 53.3 & $\mathrm{~S}, \mathrm{~T}$ \\
\hline Mus macedonicus & 340 & 26.3 & 15 & 5100 & 12.03 & $\mathrm{~S}, \mathrm{SN}, \mathrm{C}, \mathrm{Y}$ \\
\hline Microtus sp. & 137 & 10.6 & 32.5 & 4452.5 & 10.51 & $\mathrm{~S}, \mathrm{~T}$ \\
\hline Cricetulus migratorius & 110 & 8.5 & 26 & 2860 & 6.75 & $\mathrm{~T}, \mathrm{~S}$ \\
\hline Microtus levis & 59 & 4.56 & 30.2 & 1781.8 & 4.206 & $\mathrm{SN}, \mathrm{T}$ \\
\hline Apodemus sp. & 57 & 4.41 & 23.45 & 1336.65 & 3.15 & $\mathrm{O}, \mathrm{S}, \mathrm{T}, \mathrm{C}$ \\
\hline Apodemus sylvaticus & 28 & 2.16 & 22.99 & 643.72 & 1.52 & $\mathrm{O}, \mathrm{SN}, \mathrm{C}$ \\
\hline Meriones tristrami & 24 & 1.85 & 99.8 & 2395.2 & 5.65 & $\mathrm{~T}, \mathrm{~S}, \mathrm{C}$ \\
\hline Apodemus witherbyi & 17 & 1.31 & 23.62 & 401.54 & 0.95 & $\mathrm{O}, \mathrm{SN}, \mathrm{C}$ \\
\hline Crocidura suaveolens & 9 & 0.73 & 8.5 & 76.5 & 0.18 & $\mathrm{SN}, \mathrm{C}$ \\
\hline Mesocricetus brandti & 5 & 0.39 & 83.7 & 418.5 & 0.99 & $\mathrm{~S}, \mathrm{~T}$ \\
\hline Suncus etruscus & 1 & 0.08 & 2 & 2 & 0.004 & $\mathrm{SN}, \mathrm{C}$ \\
\hline Total & 1293 & 100 & 413.86 & 42377.41 & 100 & \\
\hline
\end{tabular}

*Not calculated governorate (Habitat Types: T-Agricultural, O-Forest, SN- Marshy and Damp, S-Steppe,

Ç-Brush wood, Y-Settlement) 
In this study, long-eared owl was recorded to intensively feed on small mammals inhabiting agricultural areas in the surrounding of Fatih Natural Park. Additionally, it was also observed to create a prey pressure also on rodents inhabiting in border of forests and open lands around them. Despite the fact that there is suitable ponds, agricultural areas and bushes in the forests in the study field where insectivore mammals can live, they were determined to have pellets at minimum rate. In this study, Suncus etruscus species was recorded for the first time from Yozgat and Central Anatolia.

\section{Discussion}

In numerous studies conducted with owl pellets, more than $65 \%$ of its diet consisted of species from the genus Microtus (Figure 2, Figure 3). Species from the genus Mus were recorded to be less than 20\%. In this study, while species of the genus Microtus took the first place with the rate of 53\%, the species Mus macodenicus from the genus Mus was determined to have a rate of 26\%. The species Mus macodenicus was recorded to constitute the second most significant element of the diet, following the species Microtus hartingi/lydius.

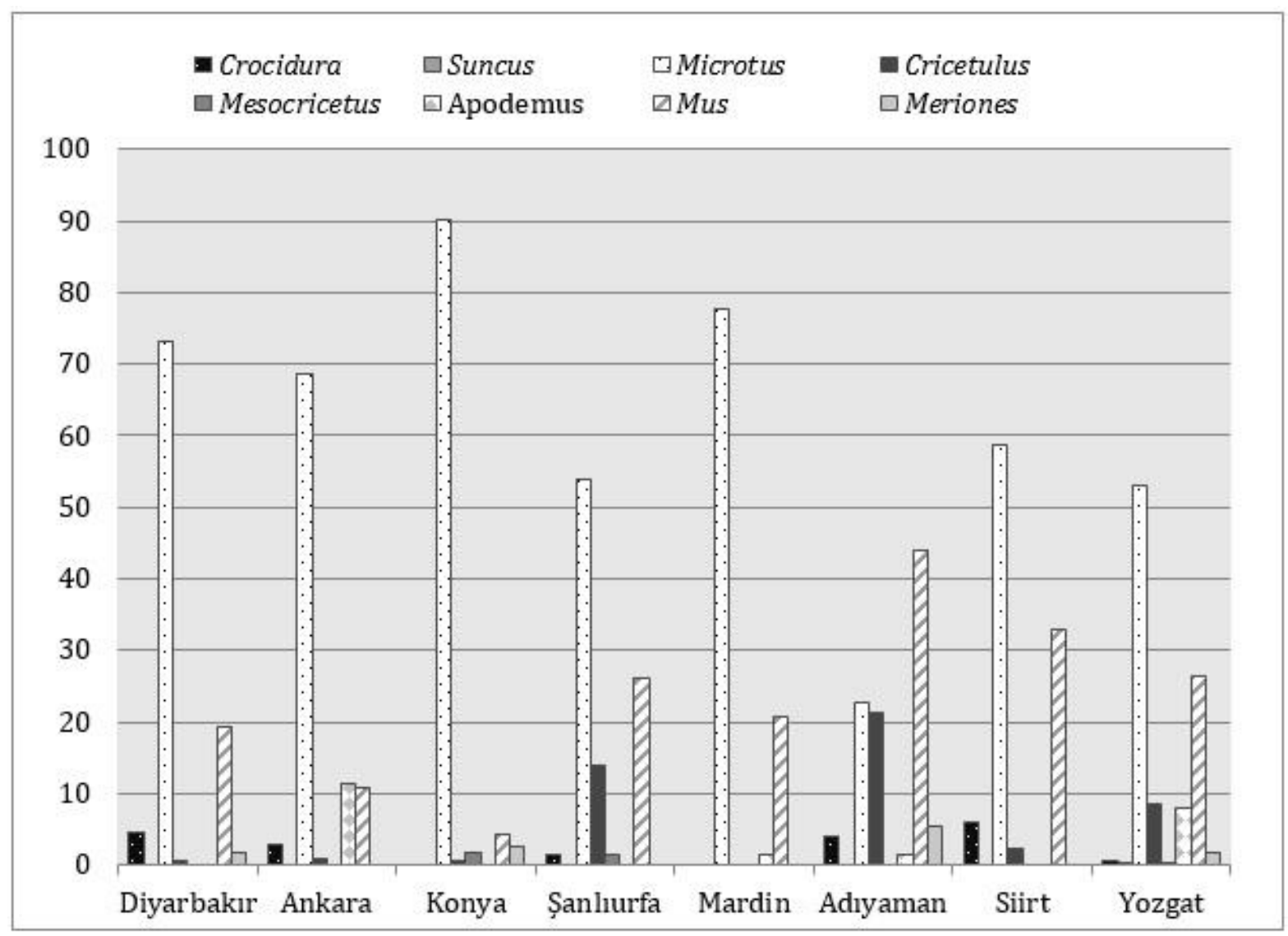

Figure 2. Comparison of percentages belonging to rodent genera with certain literature data 


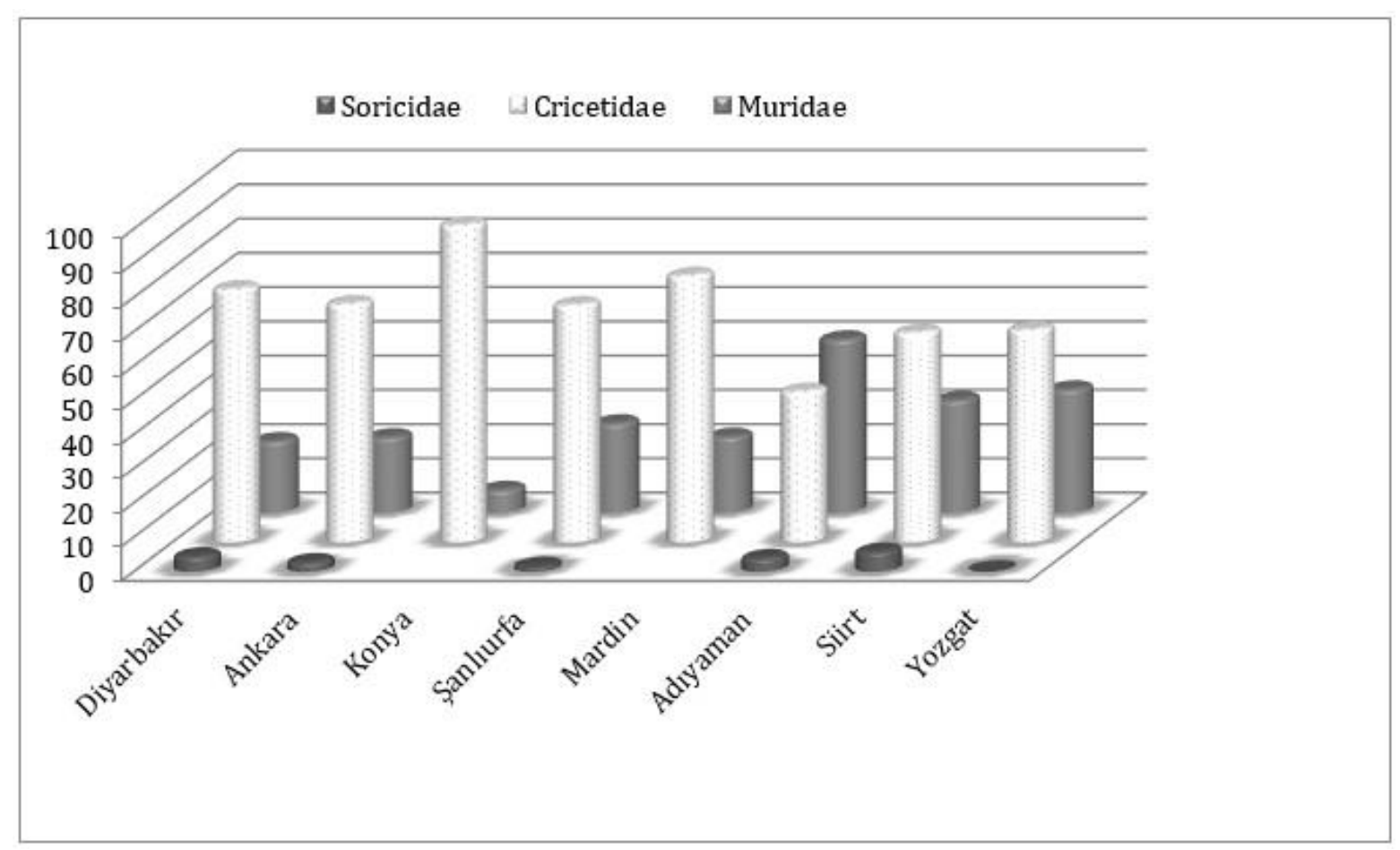

Figure 3. Comparison of percentages belonging to rodent families with some literature data

Microtus hartingi/lydius is a systematically contradictive species. Microtus guentheri was widely used in previous pellet analysis studies, however, in the recent studies conducted on systematical status of the genus Microtus, it was found that the species in Central Anatolia was not Microtus guentheri. It is still a matter of debate if this species was M. hartingi or M. lydius? [19, 30-32].The species Microtus hartingi/lydius in Central Anatolia, which is considerably larger than the species Microtus guentheri in terms of general morphological body measurements, has the greatest biomass in diet of owl.

According to Kaya and Coşkun [33], six species, Microtus guentheri, Microtus sp., Cricetulus migratorius, Meriones sp., Apodemus sp and Mesocricetus brandti species were found in 134 pellet of long-eared owl (Asio otus) collected from Erzurum. Microtus guentheri in these pellets were the most common small mammal species with a rate of $68.5 \%$. In this study, the remains of 12 mammal species were found in 1293 pellets. Microtus hartingi/lydius was the most common species.

Göçer [34] reported that the diet of the nesting Long-eared Owls consisted entirely of birds. In our study the diet of the Long-eared Owls consisted entirely of mammals.

Bulut et al. [13] reported that they found mainly pieces of skull in 138 pellets of the species Asio otus collected form Ankara province. However, 7265 (10.9\%) of 66647 pieces of bones within 706 pellets were pieces from skull in this study. The species Suncus etruscus was identified mostly in pellet analysis studies in Turkey [35]. So far, in studies based on pellet analysis, Suncus etruscus species is only recorded from southeastern Turkey. In this study, the record of the species Suncus etruscus was given from Central Anatolia for the first time.

Wheat with zinc-phosphide has been used for the control of Microtus in Yozgat province, 3616 $\mathrm{kg}$ is the amount used in 266281 decares in 2016 [36]. In this study, the effect of the species Asio otus alone on Microtus was determined. Mixtures used for chemical control purposes negatively influence organisms like particularly Asio otus which mainly feed on rodent species and are placed at top of food chain. Eradication of these species as the result of chemical poisoning would cause elimination of natural biological control on rodent species that are considered agricultural pests. Therefore, it has great importance in terms of protecting natural balance to warn relevant people about control of agricultural pests. 


\section{References}

[1] Rubolini D., Pirovano A., Borghi S. 2003. Influence of seasonality, temperature and rain fall on the winter diet of the long-earedowl. Folia Zoologica, 52: 67-76.

[2] Seçkin S., Coşkun Y. 2006. Mammalia nremains in the pellets of Long-Eared Owls (Asio otus) in Diyabakır province. Turkish Journal of Zoology, 30: 271-278.

[3] Romanowskil J., Zmihorski M. 2009. Seasonal and habitat variation in the diet of the tawny owl (Strix aluco) in Central Poland during unusually warm years. Biologia, 64: 365-369.

[4] Obuch J. 1994. Diet of Tawny Owl (Strix aluco) in selecte dregions of Bohemia and Moravia. Sylvia, 30: 77-85.

[5] Steiner H.M., Vauk G. 1966. Säugetiereaus dem Beyşehir-Gebiet (Konya, Kleinasien). Zoologi scher Anzeiger, 176: 97-102.

[6] Morgan D. 1983. An analysis of some Eagle Owl pellets from Turkey. Sandgrouse, 5: 105-106.

[7] Hoppe N. 1986.Pellet contents of the Barn Owl, near Samandağ, Turkey. Zoology in the Middle East, 1: 29-31.

[8] Kasparek M. 1985. Die Sultans sümpfe. Naturge schich teeines Vogel paradieses in Anatolien. Heidelberg, Germany.

[9] Kasparek M. 1986. On the distribution and systematic position of the Barn Owl, Tyto alba, in Turkey and adjacentareas. Zoology in the Middle East,1: 44-51.

[10] Kock D. 1990. Notes on mammals (Insectivora, Rodentia) taken by the Tawny Owl in NW Turkey. Zoology in the Middle East, 4: 5-9.

[11] Nadachowski A., Smielowski J., Rzebikkowalska B., Daoud A. 1990. Mammals from the Near East in Polish collection. Acta Zoologica Cracoviensia, 33: 91-120.

[12] Gezici V. 2009. Niğde, Nevşehir ve Aksaray illerden toplanan pelletlerle Strigiformes (Classis: Aves) ordosu üyelerinin besin analizi (Unpublished master's thesis). Niğde Üniversitesi Fen Bilimleri Enstitüsü, Niğde, Türkiye (in Turkish).

[13] Bulut Ş., Akbaba B., Ayas Z. 2012. Analysis of mammal remains from owl pellets (Asio otus), in a suburban area in Beytepe, Ankara. Hacettepe J. Biol. \&Chem., 40: 233-237.

[14] Seçkin S., Kaya A., Coşkun Y. 2012. Başaklı Köyü (Diyarbakır-Bismil) civarında yaşayan puhu (Bubo bubo)'ların peletlerin deki küçük memelilerin dağılımı. C.Ü. Fen Fakültesi Fen Bilimleri Dergisi, 33: 1 (in Turkish).

[15] Hizal E. 2013. Diet of the Long-eared Owl, Asio otus, in Central Anatolia (Aves: Strigidae). Zoology in the Middle East, 59: 118-122.

[16] Kaya A., Coşkun Y. 2014. Nevşehir'de Baykuş Peletlerindeki Memeli Hayvan Kalıntılarının Dağılımı. Nevşehir Bilim ve Teknoloji Dergisi,3: 39-44 (in Turkish).

[17] Schueler F.W. 1972. A new method of preparing owls pellets boiling in NaOH. Bird Banding, 43:142.

[18] Yalden D.W. 2009. The Analysis of Owl Pellets. Southampton, UK: The Mammal Society.

[19] Yiğit N., Çolak E. 2002. On the distribution and taxonomic status of Microtus guentheri (Danford and Alston, 1880) and Microtus lydius Blackler, 1916 (Mammalia: Rodentia) in Turkey. Turkish Journal of Zoology, 26: 197-204.

[20] Kryštufek B., Vohralík V. 2001. Mammals of Turkey and Cyprus.Order Insectivora. Knjižnica Annales Majora.

[21] Demirbaş Y., Pamukoğlu N. 2008. The Bioecology of Meriones tristrami Thomas, 1892 in Kurkkale Province (Mammalia: Rodentia). IJNES, 2: 39-44.

[22] Gözütok S., Albayrak I. 2009. Biologyand ecology of the species of the genus Microtus (Schrank, 1798) in Kirıkkale province (Mammalia: Rodentia). IJNES, 3: 94-101.

[23] Yorulmaz T., Albayrak I. 2009. Studies on the morphology and karyology on the genus Apodemus from Turkey, with some notes on the bioecology. IJNES, 3: 32-38.

[24] Pamukoglu N., Albayrak I. 1996. The rodents of Kastamonu Province (Mammalia: Rodentia). Commun Fac Sci Univ Ank Series C, 14: 1-22.

[25] Osborn D.J. 1965. Hedgehogs and shrews of Turkey. Proc. United States Nat. Mus., 117: 553566.

[26] Tez C. 2000. Taxonomy and distribution of white-toothed shrews (Crocidura) (Soricidae: Insectivora: Mammalia) of Turkey. Turkish Journal of Zoology 24: 365-374. 
[27] Kefelioğlu H., Kryštufek B. 1999. The taxonomy of Microtus socialis group (Rodentia: Microtinae) in Turkey, with the description of a new species. J Nat Hist., 33: 289-303.

[28] Coşkun Y. 1999. Diyarbakır Meriones tristrami Thomas, 1892 (Rodentia: Gerbillidae) Örneklerinin Morfolojik Özellikleri. Turkish Journal of Zoology, 23: 345-355.

[29] Yiğit N. 2003. Age-Dependent Cranial Variations in Mesocricetus brandti (Mammalia: Rodentia) Distributed in Turkey. Turkish Journal of Zoology, 27: 65-71.

[30] Kryštufek B., Vohralik V. 2009.Mammals of Turkey and Cyprus. Rodentia II: Cricetinae, Muridae, Spalacidae, Calomyscidae, Capromyidae, Hystricidae, Castoridae. Knjižnica Annales Majora.

[31] Yiğit N., Markov G., Çolak E., Kocheva M., Saygılı F., Yüce D., Çam P. 2012. Phenotypic features of the "Guentheri" group vole (Mammalia: Rodentia) in Turkey and the Southeast Bulgaria: Evidence forits taxonomic detachment. Actazool bulg., 64: 23-32.

[32] Markov G., Csorba G., Kocheva M., Gospodinova M. 2014. Skull features of the common vole (Microtus arvalis sensulato) from Hungary: craniometrical evidence for its taxonomic detachment. Turkish Journal of Zoology, 36: 283-290.

[33] Göçer E. 2016. Diet of a nesting pair of Long-eared Owls, Asiootus, in an urban environment in southwestern Turkey (Aves: Strigidae), Zoology in the Middle East, 62 (1): 25-28.

[34] Kaya A., Coşkun Y. 2017. Erzurum'dan Toplanan Kulaklı Orman Baykuşu (Asio otus) Peletlerinde Memeli Hayvan Türleri. BEÜ Fen Bilimleri Dergisi, 6 (1): 47-50.

[35] Coşkun Y., Kaya A. 2013. Additional record of Suncus etruscus (Savi, 1822) (Mammalia: Soricidae) from Southeastern Anatolia, Turkey. IUFS Journal of Biology, 72: 31-35.

[36] Anonymus, 2017. Bitki Sağlığı 2017 Y1lı Uygulama Programı Kitabı. T.C. Gida Tarım ve Hayvancılık Bakanlığı, Gıda ve Kontrol Genel Müdürlüğü, Ankara, Türkiye (in Turkish). 